\title{
Responding to extremes: managing urban water scarcity in the late nineteenth-century Straits Settlements
}

\author{
Fiona Williamson ${ }^{1}$ (D)
}

Received: 19 July 2020 / Accepted: 16 October 2020 / Published online: 29 October 2020

(c) Springer Nature B.V. 2020

\begin{abstract}
In 1877, the major towns of the Straits Settlements-Singapore, George Town, Penang Island and Malacca - suffered a drought of exceptional magnitude. The drought's natural instigator was the El Niño phase of the El Niño Southern Oscillation, a climatic phenomenon then not understood by contemporary observers. The 1877 event has been explored in some depth for countries including India, China and Australia. Its impact on Southeast Asia however is less well-known and the story of how the event unfolded in Singapore and Malaysia has not been told. This paper explores how the contemporary British government responded to the drought, arguing that its impact on hydraulic management was at best minimal yet, it did have impact on other areas, such as forest reservation with the hope of preserving future rainfall. It also highlights how, in contrast to studies on urban water plans in other British Asian colonies, the colonial authorities in the Straits Settlements had a far less coherent and meaningful relationship with water in their town planning schemes. As this paper is part of a special issue, Water History in the time of COVID-19, it has undergone modified peer review.
\end{abstract}

Keywords Straits Settlements · Drought · Urban planning · Water conservation

\section{Introduction}

In 1877, the British Straits Settlements-including the towns of Singapore, George Town, Penang Island and Malacca-suffered a drought of exceptional magnitude. Crossing 10 months from February to late November, the normal inter-monsoon period of dry

This paper is part of a special issue, Water History in the time of COVID-19. This issue was designed to be a venue for scholars who had been planning on presenting their research at academic conferences that were postponed or cancelled due to the virus. We recognize the vital importance of conference presentations for us to get feedback on work in progress, to share promising projects, and to begin meaningful conversations with peers. This special issue has undergone modified peer review, and these essays are to be seen as works in progress rather than final results; the authors welcome your feedback, conversation, and engagement.

Fiona Williamson

fwilliamson@smu.edu.sg

1 School of Social Sciences, Singapore Management University, Singapore, Singapore 
weather interspersed with severe thunderstorms (March-May) and the Southwest monsoon (June-September) did not materialise. Rainfall fell to some of the lowest levels ever known (Gao et al. 2019). The drought's natural instigator was the El Niño phase of the El Niño Southern Oscillation (ENSO), a climatic phenomenon not understood by contemporary observers. The 1877 event was one of four strongest in the historical instrumental weather record and likely the most severe of the nineteenth century, bringing drought, famine, dearth and hardship across large swathes of the globe. This paper argues that, while this event has been widely studied from social, climatic and economic perspectives for India (Singh et al. 2018; Gráda 2009), China and North Africa (Davies 2001) and, to some extent, Australia (Garden 2009), far less research has been devoted to investigating how the event impacted on Southeast Asia. In part this lack corresponds with the massive socioeconomic impacts of the event on those abovementioned countries, with water shortages, dearth and disease contributing to an estimated 20 million deaths in China alone (Davies 2001).

With a focus on only urban Singapore and Malaysia, this paper can only fill a small gap for the region, but it hopes to add to what could be a much larger discussion. It takes a close lens to two particular aspects of the drought story in the Straits Settlements. First, it explores water governance and planning during the event and in the immediate aftermath. It argues that although the drought starkly revealed a need to fast-track and improve water supplies for urban areas, the colonial British government's lackadaisical attitude toward this aspect of town planning actually hindered the process. Second, and connectedly, it investigates how contemporaries understood and later conceptualised the causes of severe drought. Without knowledge of ENSO, they considered 'desiccation'-a lessening of localised rainfall due to deforestation - as a possible explanation. Adherence to this idea had more impact on conservation policy however, wrapped up in broader concerns of saving water for agricultural purposes than for town supplies. As a whole, this paper hopes to contribute to the discussion of hydrological infrastructure within urban water history, but couched within a wider discussion of early climate theory suggesting that, in this case at least, the response of colonial officials to urban water crises says less about a coherent colonial power-nexus ${ }^{1}$ and more about colonial attitudes toward water conservation for agricultural sustainability and a nascent possibility of Anthropogenic climate change.

From 1850, there was a move toward improving urban water supplies across many of the European colonies in Asia, as coastal settlements transitioned into complex, dynamic portcities (Doshi 2017). This move was inspired by rapid population growth, but also a combination of patronage from local elites, a string of unusual meteorological crises (Davies 2001) and an improved understanding of the causes of (tropical) disease and sanitarian movements from 'home' (Doshi 2017; Broich 2007; Haynes 2001; Bynum 1988). Much of the literature on this transformational period has been critical, showing how bringing piped water to towns actually bred starker social inequalities for non-Western/poorer urban dwellers (Bashford 2014; Nilsson and Kaijser 2009). There is only a small literature on aspects of urbanisation, water, health and colonialism in the Straits Settlements (Williamson and Proust 2020; Kai and Fu 2008; Dobbs 2003; Manderson 1996; Yeoh 1993, 1996), but it likewise reveals how planning privileged the few above the many and that local communities continued to rely on traditional/natural water sources such as springs and rivers instead of, or supplement to, British provisions. It also demonstrates how local elites influenced (or

\footnotetext{
${ }^{1}$ A concise historiographical summary of this large field can be found in Morgan (2017).
} 
paid for) water schemes when the British government proved reluctant to provide sufficient support.

While the study of colonial water supply can illuminate power dynamics within urban communities, scholars have also argued that water schemes were intimately connected to modern state building (Cutler 2010; Broich 2007). I would argue, however, that the poor pace, ill-conceived and often reactive water policies of the British colonial government in the Straits Settlements added little to state building here, at this time. It was only in the 1920s, when a scheme was devised to bring a permanent supply of water from the Unfederated Malay States (Johore) to Singapore (Goh 2003) that an era began where water became highly politicised and linked to a centralisation of state power. If anything, the 1877 drought revealed even more the distance between home government and the local Legislative Council, and a general inclination by both parties to prioritise other issues over water supply. Lastly, scholarship on colonialism and climate has been revealing of how colonial powers often had difficult, anxious relationships with the climate of their adopted countries (Beattie 2011; Bhattacharya 2012; Livingstone 2002; Harrison 1994) and sought to control what they did not understand through enhancing scientific understanding of what were, in their minds, the extremes of the tropical/monsoon climate. While much of this work has been undertaken in Indian and Australian contexts, it could also be said that the colonial authorities of the Straits Settlements felt the same anxieties. Droughts played a big role in this dynamic, creating fear about resource sustainability and agricultural productivity, and a potential for declining public health (Jones 2017; Garden 2009; Davies 2001). The gradual adoption of rainfall gauges and an increasing scientific dialogue surrounding perceived climatic changes stemmed directly from these fears, aiding an effort to track and make sense of weather patterns.

\section{The drought}

For early European settlers in the Straits Settlements, the idea of drought would have seemed incongruous. Using terms such as 'verdant', 'conducive', or even 'monotonous' to describe the tropical climate, there was a general belief that the weather on the peninsula was not prone to the extremes of other British-held Asian regions, especially India and Hong Kong. 'The rain in Singapore falling in showers throughout the year, and not confined to one season', wrote Charles Buckley, the famous chronicler of Singapore, 'gives a perpetual verdure to vegetation, cools the surface of the earth, and precipitates ... the generation of any atmospheric malaria' (Buckley 1902). Although this image of tropicality proved enduring, drought, especially during the driest months of February-March, proved a regular feature of the climate. Especially severe droughts had occurred in 1842, 1849, 1855 and 1864, but 1877 was exceptional. By April the normal dry weather had not broken, public health was deteriorating, and the antiquated and inadequate reservoirs were failing to meet demand.

Stories began emerging in April bemoaning the poor state of urban drains and streams. In Malacca, streams where dhobies (washer-men of Indian origin) worked were said to have entirely dried up (Straits Times Overland Journal, 28 April 1877). In Singapore, smells emanating from a stream that ran through the town centre were described as 'unbearable' as each low tide exposed the deep sludge on its bed (Straits Times Overland Journal, 12 May 1877). Contemporaries noted how the municipal authorities were fuelling the stink by dumping lime into watercourses, at that time the main method of 
sterilising drains in an effort to prevent cholera (The Straits Times, 21 April 1877). Noting the 'remarkable ... great heat' and its 'baneful effect on the health of the community owing to the consequent scarcity and bad quality of the water', fears of a major cholera epidemic became rife as cases increased (Straits Times Overland Journal, 19 April 1877). By month-end panic broke-out as stories that government were supressing the true mortality figures circulated (Straits Times Overland Journal, 28 April 1877).

Some of these stories may have held more than grain of truth. On 5 May, a Straits Times correspondent appeared to confirm rumours that outlying villages were suffering from a lack of wholesome water. The wells, he argued, were too shallow to be either effective or healthy and 'the Malays are dying off like flies ... There were seven deaths yesterday and five the day before ... there is little or no water to be got ... and what there is, is exceedingly bad' (The Straits Times, 5 May 1877). Most reports agreed that the problem was the worst for the poorest inhabitants, who could not access a reliable, clean water supply (Straits Times Overland Journal, 19 April 1877). In George Town too, the authorities were forced to release one-hundred prisoners from overcrowded cells to curb cholera from rampaging unchecked through the old gaol. Forty-two men still died. Principle Civil Medical Officer Thomas Irvine Rowell noted how the cholera 'was, in no doubt, result of the drought, and the consequent deficiency of wholesome drinking water' and a bout of smallpox, while not blamed on the weather per se, was 'at its height in the hot and dry months of Jan-April and was of the most virulent type' (Government Gazette, Annual Medical Report for 1877). In desperation, even untried pseudo-scientific theories began to be vaunted to trigger rain, including cannonading using artillery and gunpowder held at the garrison in Fort Canning, Singapore (Straits Times Overland Journal, 28 April 1877, p. 7).

The drought continued into the autumn bringing with it sporadic new outbreaks of cholera, the loss of many important plant species at the botanic gardens (Murton 1877), and a failed fruit and rice harvest, especially in Malacca where fears grew of an impending famine (Straits Times Overland Journal, 2 November 1877, p. 9). Tin, one of the colonies biggest exports, was also impacted as its mining relied on large, constant water supplies for extraction (Jarman 1998a, Vol. 2). Fires became common and were to be feared. In Singapore during November, for example, a major fire started in the grounds of a bungalow in the wealthy European Tanglin area, caused by a stray spark in the lalang (weeds) which were 'dry as tinder owing to the prolonged drought' (The Straits Times, 24 November 1877). Ironically, the worst fire that year also had the unintended consequence of worsening the drought in Singapore.

At the start of 1877, Singapore's main waterworks comprised a small reservoir and pumping station at the foot of Fort Canning, which provided most of the town's piped water supplies and wells. The pumping station was coal powered; the coal stored at Tanjong Pagar Docks (Fig. 1).

The coal was stored in sheds thatched with attap, a palm commonly used in Southeast Asia for roofing. On 13 April, a blaze started that, with the 'great heat and drought ... rendered those buildings literally as flammable as ... gunpowder' (The Straits Times, 14 April 1877). The coals were aflame all night, despite the best efforts of the fire brigade, military, police and public combined; the lack of available water to fight the fire was a major contributing factor in the eventual loss of around 30,000 tonnes of coal (The Straits Times, 14 April 1877). While many (never answered) questions were asked about how the fire had started, the biggest question that year was: why was there not an alternative water supply? 


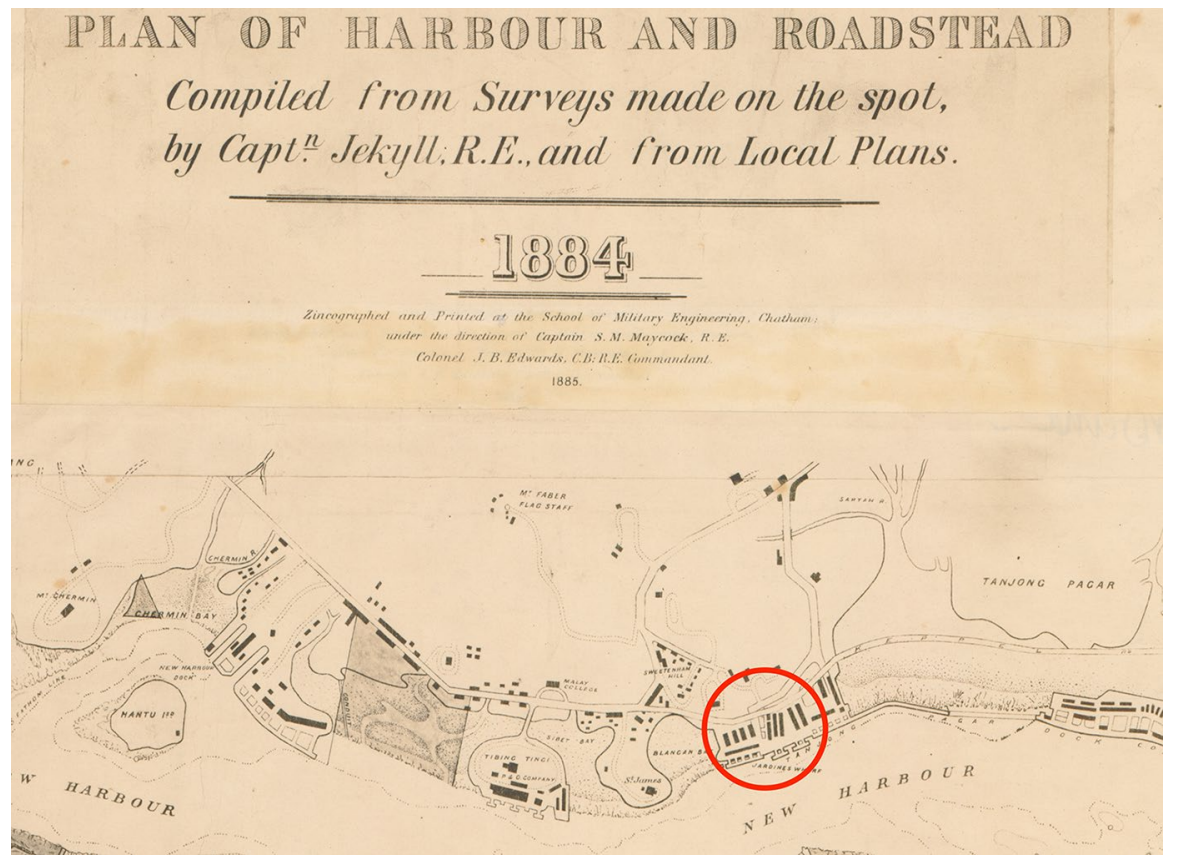

Fig. 1 Extract from URA Singapore Plan of Harbour and Roadstead 1885, ref: 20120001620 (circle denotes the Tanjong Pagar docks)

\section{Urban water provision in the Straits Settlements}

The question of a water supply for Singapore was dogged with controversy. A small reservoir and waterworks had been commissioned within the first year of British administration at the base of Fort Canning, but by the 1830s were insufficient to meet the demands of the rising population. Indeed, their main purpose was to supply water to ships docked in port (Dobbs 2003), not the urban populace who made up the shortfall with wells and streams. John Snow's 1854 discovery that cholera was transmitted through polluted water, along with a growing sanitarian movement, meant that a reliable supply of clean, piped water was considered imperative by many inhabitants.

Amid growing concerns about the healthiness of well water supplies, public pressure mounted on government to provide another waterworks and a piped supply system (Yeoh 1993). A small grant for an additional water tank at the bottom of Government Hill had been awarded by the Municipal Committee in 1856, intended to be a back-up supply during times of unusual drought (Singapore Free Press 1856). This can clearly be seen on the 1878 map, along with other wells at the bottom of the hill (Fig. 2). However, the general feeling was that these would not be sufficient to meet the growing needs of the town, especially in an emergency.

Tan Kim Seng, one of the committee members behind awarding extra monies for water supplies in 1856, also felt that the problem necessitated more than one extra emergency tank. The following year he donated $\$ 13,000$ of his own money to improving the town's water supply. As a result of his philanthropy, plans were drawn up for a proper waterworks, but the slow grinding wheels of administration and much politicking - the 


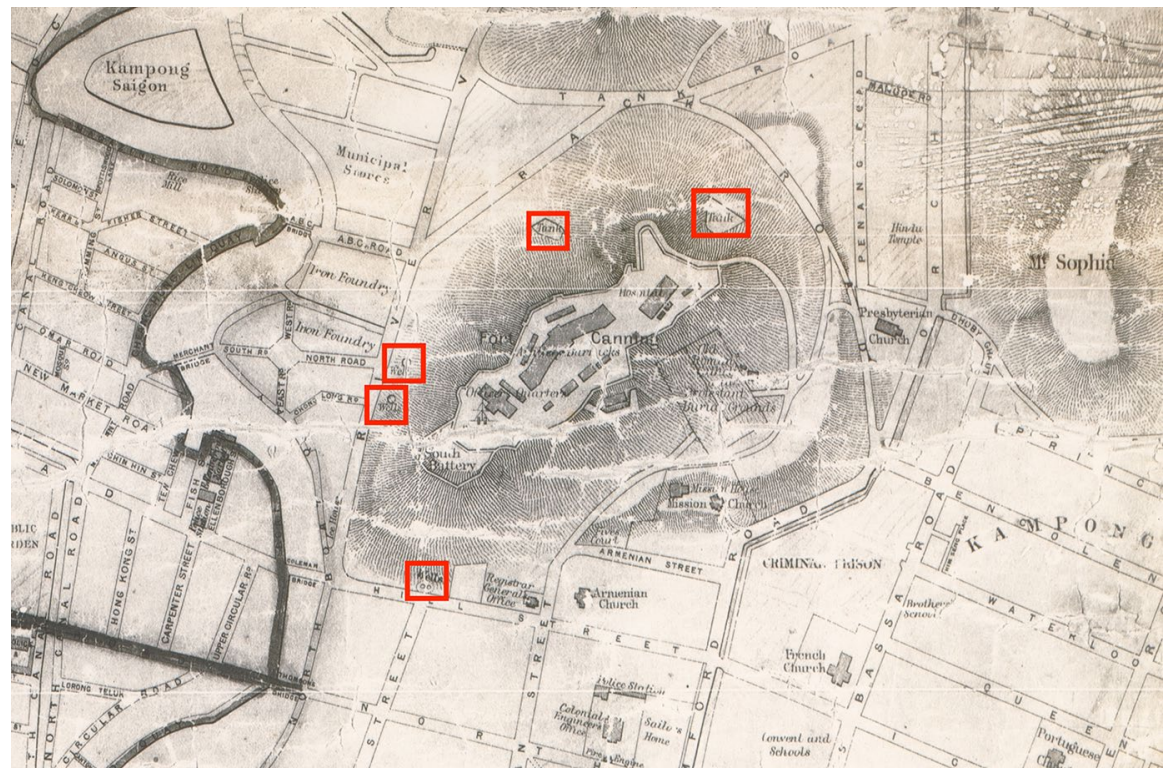

Fig. 2 Extract from Urban Redevelopment Authority (URA), Singapore, Map of the Town and Environs of Singapore 1878, 20120001620—0011 (squares denote wells and water tank)

later centred on how to finance the remainder of the project-meant that work did not start for some years (Read 1901). The reservoir and waterworks were constructed to the north of the settlement at Toa Payoh on the gravitation principle, a supply system imported directly from England into many of the Britain's Asian colonies (Broich 2007), and completed in 1867. It was soon discovered, however, that it had not been built at a sufficient height to provide the pressure needed to drive the water to the town. Advice was sought from Consulting Engineer Robert Rawlinson on how to improve the design, all of which plans were drawn up in London, in part during a visit by Singapore's own engineer John McNair — then Colonial Engineer and Surveyor-General-in the early 1870s (Rajendra 1976). Another loan had to be raised to fund new earthworks and to install additional pipes, pumps and apparatus (Straits Times Overland Journal 1873 ). Work continued across the decade with a projected $\$ 25,000$ expected to complete the project in 1877 alone (Government Gazette, 2 December 1876, p. 974).

By the time of the 1877 drought, the reservoir was still not operational. An anonymous poem published in The Straits Times that August implies how frustrated inhabitants must have been:

\section{Address to the Waterworks Reservoir}

Hail new created Lake, that shines

Brighter than ever the Chindrass Mines

In the tongue, or the brains of Fisher,

We're waiting aweary to have you down

To cleanse, and refresh our fair, filthy town

And the skin of every ardent well-wisher.

How long we have waited, how much we have spent

This old aqueduct in bad brick and cement 
Of dead dollars, can tell a sad tale ...

(Straits Times Overland Journal, 18 August 1877, p. 15).

The severity of the drought placed the Municipal Government under immense pressure to complete the project. During July, the Colonial Engineer added his voice to calls for an emergency loan to contract out the last jobs and to purchase the 198 tonnes of coal needed to power the new pumping station (Singapore Daily Times, 26 September 1877, p. 2). The bill was paid for by imposing a new water rate on houses and buildings that would benefit directly from the supply, one that was levied on a sliding scale appropriate to the value of the property (Government Gazette, 14 September 1877, pp. 549-552).

It is not entirely clear when the waterworks began operations, but it was likely some time during very late October $1877 .{ }^{2}$ At the end of that month and into November, the press and the minutes of the Legislative and Municipal Council meetings were full of selfcongratulatory remarks, praising the effort and suggesting that the reservoir had saved the day (Straits Times Overland Journal, 2 November 1877, p. 13). New Governor William Robinson, for instance, had noted at a Legislative Council meeting how opening the works, despite the cost, had greatly benefitted the town, especially the poorer classes who now had access to a regular, pure water supply (The Straits Times, 17 November 1877, p. 3). Despite the hyperbole, the reality may not have been so rosy. Other sources suggested that the new supply was only available for a few hours a day and was not especially efficient (Singapore Daily Times, 17 December 1877, p. 3). At the same time, there was a healthy amount of scepticism poured onto the claim that the new works purportedly helped the poor. Another report, for example, suggested that hundreds of people were forced to queue for hours to fill their buckets, because the water pressure was so low, whereas meanwhile gallons of water freely escaped the old reservoir at the foot of Government Hill (The Straits Times, 22 December 1877, p. 6).

Elsewhere in the Straits Settlements, it was a similar picture. In George Town, the earliest works were a brick aqueduct that channelled supplies from the waterfall at Mount Olivia to the town, a distance of some six miles, commissioned by then Governor Robert Townsend Farquhar in 1804. This supplied ships in port and also connected several domestic and civic buildings through a system of earthenware pipes (Hussin 2007). The aqueduct was rebuilt in the 1830s, as the population had more than doubled since its 1805 opening and the structure was in a poor state (Newbold 1839; Singapore Chronicle 1831, p. 1). But, by the mid-1870s, little had changed. An additional reservoir had been built at Ayer Hitam, a hill range west of the main settlement, and the scheme at Mount Olivia had been extended down into Pulau Tikus, an area eventually converted into Waterfall Gardens (botanic gardens). More improvements were under discussion, particularly whether the main supply at Pulau Tikus ought to be expanded (Government Gazette 1875), but there were few concrete plans until 1881 (Government Gazette 1881). Apart from these reservoirs, wells, springs and river channels still provided the main water source for many.

\footnotetext{
${ }^{2}$ Maintenance bills start from November 1877 though the official opening was slightly later: Straits Settlements Government Gazette 26 December 1879, p. 2028.
} 


\section{Connecting climate theories: dealing with desiccation as a means to mitigate drought}

The scale and severity of the drought fuelled speculation as to its causes. Concerned whether another such dry year might reoccur and how often, the colonial authorities looked to scientific explanations for shifts in the climate. One such theory was desiccation. This linked deforestation to changes to lessened rainfall. The field had come to prominence internationally across the nineteenth century, influenced by naturalists and scientists including Alexander von Humboldt and Jean-Baptiste Boussingault, amongst others (Bennett and Kruger 2015). The situation in European colonies in particular presented microcosmic examples of rapid land-use change, alerting people to how deforestation led to soil erosion and desertification (Grove 1994).

The question of whether deforestation was causing aridity had been a prominent discussion point in the Straits Settlements since the late 1840s, responding to concerns over the massive land transformation that had taken place in the first few decades of British rule (Logan 1848). In Penang, for instance, much of the virgin jungle in the valley and hills had been cultivated for rice, pepper and spices and interlaced with new roads and houses by 1830 (Ward 1830). By the 1860s, deforestation had caught the imagination of the British administration, given the potential for resource depletion. In 1865, Alexander Maingay-a surgeon and magistrate stationed at Malacca-was commissioned to compile a report on forests and timber reserves for that region. Maingay's survey was damning, blaming shifting cultivators - especially those involved in tapioca and hill paddy farming — and plantation owners for severe denudation. As Logan had mooted over a decade previously, 'the ruin of the forest' Maingay claimed, meant 'a corresponding diminution of the rain fall and a general elevation of the temperature, with an increasing prevalence of long droughts' (Maingay 1865).

The report unleashed an outpouring of opinion in the press over the following months. 'We are indeed glad to find him speaking out so boldly in defence of the preservation of our forests' wrote the editor of The Straits Times approvingly on 9 September. 'We have long protested against the[ir] gradual destruction' he continued 'and we earnestly recommend consideration to one of the concluding sentences in Dr Maingay's letter in which he makes the following remarkable statement. "I consider that the forests alone prevent the Malayan Peninsula from becoming an absolutely arid and relatively sterile, as Aden, the Ladrone Islands, or HongKong [sic]"' (Straits Times, 9 September 1865, p. 1).

The Malayan discussion connected with what scholars have noted was an intense period in the desiccation narrative in other colonial countries (Legg 2014). An uptick in press coverage after $1877^{3}$ was quickly followed by discussion in government. In 1879 , Colonial Secretary Cecil Clementi Smith requested John McNair to conduct a survey of forests and timber reserves for the whole of the Straits Settlements, not just Malacca as Maingay had done. Clementi Smith particularly requested McNair to investigate the 'question of rainfall, and the relation that it bears to the retention or otherwise of our forest land' (McNair 1879). The resultant report was highly critical of what McNair saw as a lack of coherent government policy on forests, the result an indiscriminate and widespread wastage

\footnotetext{
${ }^{3}$ For example, 'Effects of Forest Denudation', The Straits Times, 10 January 1874, p. 5; 'Deforestation', The Straits Times, 25 May 1878, p. 3, 'The Rainfall', The Straits Times, 29 June 1878, p. 5; 'Forest Tree Planting and its influence on climate', The Straits Times, 20 July 1878, p. 1.
} 
of quality timber and the proliferation of illegal and legal felling and charcoal burning (McNair 1879).

With memories of the recent great drought in the forefront of people's minds, efforts to direct more attention to forest preservation and planting new trees began in earnest in the early 1880s. Of course, the economic motives for forest conservation should not be underestimated (Vandergeest and Lee Peluso 2006; Kathirithamby-Wells 2005; Barton 2001), but the possibility that forest denudation might also decrease rainfall and cause droughts, had become a meaningful factor in the ongoing discussion. Nathanial Cantley, Director for the Singapore Botanic Gardens from 1880, for instance, argued that because of the unchecked destruction, showers had become less frequent, more localized, and had caused droughts of unprecedented length. This was all good reason to recommend areas for reserved forest to bring rainfall intensity and frequency back to normal (Cantley 1882a). As well as setting out 11,554 acres of reserved forest land in Singapore alone (Cantley $1882 \mathrm{~b}$ ) and planting new trees on Penang Island (Government Gazette 1885), there was an unprecedented effort made to install new rain gauges across the peninsula. These would enable analysis of long-term rainfall trends in order to understand the relationship between rainfall and deforestation. Just between 1884 and 1885, for example, eighteen new stations were made functional, including seven in Singapore and three in Penang (Irvine-Rowell 1885). Dealing with desiccation and establishing rainfall patterns offered another avenue to mitigate drought, alongside improving the supply system.

\section{Conclusion}

Talk of drought quietened during early 1878 as the Northeast Monsoon returned, albeit somewhat more subdued than normal. ${ }^{4}$ What were its legacies? While stories had circulated in the press of hardships suffered amongst some of the towns' poorer Malay and Chinese communities and there had been fear about an impending cholera epidemic, official figures compiled for the year do not support this. Mortality rates were mostly consistent with population growth and, bar the outbreak at the Convict Gaol Hospital in George Town, cholera, while elevated, did not reach epidemic proportions (Government Gazette 1878). While official reports may well have overridden the realities of water famine in local communities, it has been almost impossible to find concrete evidence of its impacts on communities and individuals.

The drought certainly lent immediate urgency to plans to improve water supplies, but the momentum lapsed fairly fast. In Singapore, another new waterworks was completed in 1878 to complement two small pre-existing reservoirs at the easterly Mount Emily. But it was the 1930s before two new impounding reservoirs were built and a new agreement for piping water across the Johore Strait from the peninsula would go some way to meeting Singapore's growing needs (Yeoh 2003). Until then, every major drought—such as in 1883,1885, 1892, 1895 or 1902-resulted in water shortages. At the height of the 1902 (also El Niño related) drought, for instance, the water supply was cut to 2 h a day (The Straits Times 1902). George Town fared even worse. After the transfer of colonial authority from India to London in 1867, any remaining executive

\footnotetext{
413.93 inches in Singapore; 4.04 inches in Penang and 5.09 inches in Malacca: Straits Settlements Government Gazette, 14 June 1878, p. 852. A 'normal' year might entail around 29 inches for Singapore, less at the other Settlements.
} 
power had passed from George Town to Singapore under the auspices of a new Legislative Council. As capital and the largest port, Singapore generally attracted more financial preference from London and had the ability to raise more rates for funding civic projects than her more northerly counterpart. The much-discussed plans to expand the water provisions in northwestern George Town around Pulau Tikus and Mount Olivia were not planned formally until 1882 (Government Gazette 1882) and not actually completed until the mid-1880s. The Ayer Hitam reservoir and waterworks also desperately needed a major overhaul and, although a great deal of money and time was spent on works in 1885 (Government Gazette 1886), the full extension was not completed until 1892. While this was a critical moment in mitigating the effects of a long drought that wiped out that year's Northeast Monsoon, prior to this, George Town's inhabitants had regularly not had access to 'water between 8 am and 8 pm in the dry months' (Jarman 1998b, Vol. 4). Indeed, the municipal minutes before 1892 are littered with complaints concerning the limited supply and associated public health problems, not just during drought periods.

By looking at the experience of drought, this study contends water shortages did not necessarily lead to obvious conclusions, i.e. improving urban water supplies. The British were ill (or un)-prepared to manage urban water here, despite what scholars such as Dossal (1991) or Broich (2007) have found for other British Asian colonies. Rather than water becoming part of an urban power dynamic and despite a certain level of problematic dependency by local populations on imported British water schemes evident in Singapore and George Town, the government's half-hearted approach and often long-drawn-out planning phases, meant that their recalcitrance may have worked to undermine their authority in this area. As Rohan D'Souza has convincingly argued for hydraulic management in India (D'Souza 2020), the British approach to water, while often part of a quest to impose control over the uncontrollable, was often only a partial success. It can be argued instead that the experience of drought actually had more impact across other areas of British planning, in particular forestry and meteorology where the possibility of Anthropogenic climate change did directly impact policy for resource preservation. It is perhaps here that we see the biggest interest and investment in water management in the Straits Settlements at this time.

Acknowledgements The author wishes to thank Ahmad Bin Osman, Research Assistant to this project for his diligent research and intellectual contributions. In addition, the author also wishes to gratefully acknowledge the Singapore Ministry of Education Tier 1 scheme (Grant Award 19-C242-SMU-003) for funding this project and the School of Social Sciences and Office of Core Curriculum at Singapore Management University for their kind support throughout.

Funding This research was kindly sponsored by the Singapore Ministry of Education under the Grant MOET1 19-C242-SMU-003 Reconstructing El Niño in Singapore and Malaysia: a multi-disciplinary approach.

Data availability Upon request to the author.

Code availability Not applicable.

\section{Compliance with ethical standards}

Conflict of interest None.

Ethical approval None. 
Informed Consent None required.

\section{References}

Barton G (2001) Empire forestry and the origins of environmentalism. J Hist Geogr 27(4):529-552

Bashford A (2014) Imperial hygiene: a critical history of colonialism, nationalism and public health. Palgrave Macmillan, Basingstoke

Beattie J (2011) Empire and environmental anxiety, 1800-1920: health, science, art and conservation in South Asia and Australasia. Palgrave Macmillan, Basingstoke

Bennett B, Kruger F (2015) Forestry and water conservation in South Africa: history, science and policy. ANU Press, Canberra

Bhattacharya N (2012) Contagion and enclaves: tropical medicine in colonial India. Liverpool University Press, Liverpool

Broich J (2007) Engineering the empire: British water supply systems and colonial societies, 1850-1900. J Br Stud 46(02):346-365

Buckley CB (1902) An anecdotal history of Singapore 1819-1867, vol 2. Fraser and Neave, Singapore

Bynum W (1988) Ideology and health care in Britain: Chadwick to Beveridge. Hist Philos Life Sci 10:75-87

Cantley N (1882a) Report on the Forests of the Straits Settlements, 1882. Annual report on the botanic gardens, Singapore, 1884. Singapore

Cantley N (1882b) Map of the Island of Singapore. Annex to report on the forests of the Straits Settlements. Singapore

Cutler B (2010) Imperial thirst: water and colonial administration in Algeria, 1840-1880. Rev Middle East Stud 44(2):167-175

Davies M (2001) Late Victorian Holocausts: El Niño Famines and the Making of the Third World. Verso, London

Dobbs S (2003) The Singapore River: a social history, 1819-2002. Singapore University Press, Singapore

Doshi S (2017) Imperial water, urban crisis: a political ecology of colonial state formation in Bombay, 1850-1890. Review (Fernand Braudel Center) 37(3-4):173-218

Dossal M (1991) Imperial designs and Indian realities: the planning of Bombay City, 1845-1875. Oxford University Press, Oxford

D'Souza R (2020) Event, process and pulse: resituating floods in environmental histories of South Asia. Environ Hist 26(1):31-49

Gao E, Timbal B, Williamson F (2019) Creating Singapore's longest monthly rainfall record from 1839 to the present. MSS Res Lett 2:3-11

Garden D (2009) Droughts, floods \& cyclones: El Niños that shaped our colonial past. Australian Scholarly Publishing, Melbourne

Goh KC (2003) Water supply in Singapore: challenges and choices. Greener Manag Int 42:77-86

Gráda CO (2009) Famine: a short history. Princeton University Press, Princeton

Grove R (1994) Green imperialism: colonial expansion, tropical Island Edens and the origins of environmentalism, 1600-1860. Cambridge University Press, Cambridge

Harrison M (1994) Public health in British India: Anglo-Indian preventative medicine, 1859-1914. Cambridge University Press, Cambridge

Haynes DM (2001) Imperial medicine: Patrick Manson and the conquest of tropical disease. University of Pennsylvania Press, Philadelphia

Hussin N (2007) Trade and Society in the Straits of Melaka: Dutch Melaka and English Penang, 1780-1830. NUS Press, Singapore, pp 237-245

Irvine-Rowell $\mathrm{T}$ (1885) Meteorological report, for the year 1885'. J Straits Branch R Asiat Soc 16(385-411):389

Jarman D (1998a) Annual reports of the Straits Settlements 1855-1941, vol 2. Archive Editions, Slough Jarman D (1998b) Annual reports of the Straits Settlements 1855-1941, vol 4. Archive Editions, Slough Jones R (2017) Slow Catastrophes: living with drought in Australia. Monash University Publishing, Clayton

Kai PH, Fu K (2008) From colony to global city: public health strategies and the control of disease in Singapore. In: Lewis M, MacPherson K (eds) Public health in Asia and the Pacific: historical and comparative perspectives. Routledge, London and New York, pp 188-205

Kathirithamby-Wells J (2005) Nature and nation: forests and development in peninsula malaysia. Singapore, NUS Press 
Legg S (2014) Debating the climatological role of forests in Australia, 1827-1949: a survey of the popular press. In: Beattie J et al (eds) Climate, science, and colonisation: histories from Australia and New Zealand. Palgrave Macmillan, New York, pp 119-136

Livingstone D (2002) Tropical hermeneutics and the climatic imagination. Geographische Zeitschrift 90(2):65-88

Logan JR (1848) The probable effects of the climate of Pinang on the continued destruction of its hill jungles. J Indian Archipel East Asia 2:534-536

Manderson L (1996) Sickness and the state: health and illness in colonial Malaya, 1870-1940. Cambridge University Press, Cambridge

Maingay AC (1865) Report on the timber and forest conservancy of Malacca, 20 August 1865, Straits Settlements Government Gazette, 1 September 1865, pp 387-388

McNair JFA (1879) Report by the colonial engineer on the timber forests in the Malayan Peninsula, 21 June, 1879. Straits Settlements Government Gazette, pp 893-903

Morgan RA (2017) The Anthropocene as hydro-social cycle: histories of water and technology for the age of humans. Icon 23:36-54

Murton H J report to J. Douglas, Chairman Gardens Committee, 28 Sept 1877.

Newbold TJ (1839) Political and statistical account of the British settlements in the Straits of Malacca, vol 1. John Murray, London

Nilsson D, Kaijser A (2009) Discrimination by default: the post-colonial heritage of urban water provision in East Africa. In: Castro JE, Heller L (eds) Water and sanitation services: public policy and management. Earthscan, London, pp 259-275

Rajendra N (1976) The Straits Settlements 1867-1874. Australian National University, Canberra

Read WHM (1901) Play and politics: recollections of Malaya. Wells Gardner, Darton \& Co, London

Singh D et al (2018) Climate and the Global Famine of 1876-78. J Clim 31(23):9445-9467

Singapore Chronicle and Commercial Register, 24 March 1831, p 1

Singapore Free Press and Mercantile Advertiser, 14 February 1856, p 3

Singapore Daily Times, 26 September 1877, p 2 (Correspondence between Colonial Secretary's Office and Colonial Engineer's Office, 16 July 1877)

Singapore Daily Times, 17 December 1877, p 3

Straits Settlements Government Gazette Extraordinary: Colonial Estimates_1877. 2 December 1876, p 974

Straits Settlements Government Gazette, 30 January 1875, p 136

Straits Settlements Government Gazette, 14 October 1881, p 894

Straits Settlements Government Gazette, 16 June 1882, p 600

Straits Settlements Government Gazette, 12 May 1885, p 724

Straits Settlements Government Gazette, 13 July 1886, p 1128

Straits Settlements Government Gazette: A Bill to impose a Water-rate within certain parts of the Settlement of Singapore, 14 September 1877, pp 549-552

Straits Settlements Government Gazette: Annual Medical Report of the Civil Hospitals in the Straits Settlements for the year 1877, 5 November 1878, pp 109-110

Straits Settlements Government Gazette: CO276-10, Copy of Colonial Engineer's Minute on Survey, dated 27 August 1878, 3 October 1879, p 893

Straits Times Overland Journal, 19 April 1877, pp 4, 11

Straits Times Overland Journal, 28 April 1877, pp 1, 6, 7

Straits Times Overland Journal, 12 May 1877, p 9

Straits Times Overland Journal, 13 July 1873, p 6

Straits Times Overland Journal, 18 August 1877, p 15

Straits Times Overland Journal, 2 November 1877, p 9

Straits Times Overland Journal, 2 November 1877, p 13 (Report from Saturday 26 October)

The Straits Times, 9 September 1865, p 1

The Straits Times, 14 April 1877, p 2

The Straits Times, 21 April 1877, p 4

The Straits Times, 5 May 1877, p 3

The Straits Times, 17 November 1877, p 3 (Legislative Council Minutes 16 November 1877)

The Straits Times, 24 November 1877, p 3

The Straits Times, 22 December 1877, p 6

The Straits Times, 29 August 1902, p 4

Vandergeest P, Lee Peluso N (2006) Empire of forestry: professional forestry and state power in Southeast Asia, part 2. Environ Hist 12:359-393

Ward TM (1830) Contributions to the medical topography of Prince of Wales Island, Or Pulo Pinang. In: Ward TM, Grant JP (eds) Official papers on the medical statistics and topgraphy of Malacca and Prince 
of Wales Island and on the prevailing diseases of the Tenasserim Coast. Government Press, Pinang, pp 60-117, 61. Sourced from the Wellcome Collection online: https://wellcomecollection.org/works/ uhqkbwe2

Williamson F, Proust K (2020) 'Living in a state of filth and indifference to ... their health': Weather, public health and urban governance in colonial george town, Penang. Environ Hist 26(2):233-260

Yeoh B (1993) Urban sanitation, health and water supply in late nineteenth and early twentieth century colonial Singapore. Southeast Asia Res 1(2):143-172

Yeoh B (1996) Contesting space: power relations and the built environment in colonial Singapore. Oxford University Press, Kuala Lumpur

Yeoh BSA (2003) Contesting space in colonial Singapore: power relations and the built environment. NUS Press, Singapore

Publisher's Note Springer Nature remains neutral with regard to jurisdictional claims in published maps and institutional affiliations. 